\title{
Stabilization of Pt monolayer catalysts under harsh conditions of
}

\section{fuel cells}

Xiaoming Zhang, ${ }^{1}$ Shansheng $\mathrm{Yu}^{1}$, Liang Qiao ${ }^{1,3}$, Weitao Zheng ${ }^{1 *}$ and Ping Liu ${ }^{2 *}$

${ }^{1}$ Department of Materials Science, Key Laboratory of Mobile Materials, MOE, and State Key Laboratory of Superhard Materials, Jilin University, Changchun 130012, PR China.

${ }^{2}$ Center for Functional Nanomaterials, Brookhaven National Laboratory, NY 11973, USA

${ }^{3}$ College of Science, Changchun University, Changchun 130022, PR China.

Keywords: Pt monolayer, Pseudomorphic surface alloy, Acid/Alkaline solution, Stability, ORR, DFT

* Corresponding author: Weitao Zheng, e-mail: wtzheng@jilu.edu.cn \& Ping Liu, e-mail: pingliu3@bnl.gov 


\begin{abstract}
We employed density functional theory (DFT) to explore the stability of core $(\mathrm{M}=\mathrm{Cu}, \mathrm{Ru}, \mathrm{Rh}, \mathrm{Pd}, \mathrm{Ag}, \mathrm{Os}, \mathrm{Ir}, \mathrm{Au})$-shell $(\mathrm{Pt})$ catalysts under harsh conditions, including solutions and reaction intermediates involved in the oxygen reduction reaction (ORR) in fuel cells. A pseudomorphic surface alloy (PSA) with a Pt monolayer $\left(\mathrm{Pt}_{1 \mathrm{ML}}\right)$ supported on a $\mathrm{M}$ surface, $\mathrm{Pt}_{1 \mathrm{ML}} \mathrm{M}(111)$ or $(001)$, was considered as a model system. Different sets of candidate $M$ cores were identified to achieve a stable $\mathrm{Pt}_{1 \mathrm{ML}}$ shell depending on the conditions. In vacuum conditions, the $\mathrm{Pt}_{1 \mathrm{ML}}$ shell can be stabilized on the most of $\mathrm{M}$ cores except $\mathrm{Cu}, \mathrm{Ag}$ and $\mathrm{Au}$. The situation varies under various electrochemical conditions. Depending on the solutions and the operating reaction pathways of the ORR, different $\mathrm{M}$ should be considered. Pd and Ir are the only core metals studied, being able to keep the $\mathrm{Pt}_{\mathrm{ML}}$ shell intact in perchloric acid, sulfuric acid, phosphoric acid and alkaline solutions as well as under the ORR conditions via different pathways. Ru and Os cores should also be paid attention, which only fall during the ORR via the *OOH intermediate. Rh core works well as long as the ORR does not undergo the pathway via $* O$ intermediate. Our results show that PSAs can behave differently from the near surface alloy (NSA), $\mathrm{Pt}_{1 \mathrm{ML}} / \mathrm{M}_{1 \mathrm{ML}} / \mathrm{Pt}(111)$, highlighting the importance of considering both chemical environments and the atomic structures in rational design of highly stable core-shell nanocatalysts. Finally, the roles that d-band center of a core $\mathrm{M}$ played in determining the stability of supported $\mathrm{Pt}_{1 \mathrm{ML}}$ shell was also discussed.
\end{abstract}




\section{Introduction}

Pt monolayer $\left(\mathrm{Pt}_{1 \mathrm{ML}}\right)$ catalysts on metal $(\mathrm{M})$ supports, or $\mathrm{M}$ core- $\mathrm{Pt}$ shell, have attracted considerable attentions as advanced catalysts, being able to accelerate the slow oxygen reduction reaction (ORR) in fuel cells and reduce the Pt loading. ${ }^{1-6}$ To understand the promoting effect, extensive theoretical studies have been carried out; ${ }^{7-}$ ${ }^{13}$ however little attention has been paid for the stability of $\mathrm{Pt}_{\mathrm{ML}}$ shell, ${ }^{3,14,15}$ which is critical to achieve the durable activity required for commercialization. Systematic theoretical studies were reported on the stability of the $\mathrm{Pt}_{\mathrm{ML}}$ shell supported on various metal cores; ${ }^{13,16-21}$ yet the harsh operating conditions of fuel cell, in particular the solutions, had been paid little attention, which could induce the segregation of core metals to the surface and the decreased activity and stability. ${ }^{15,22,23}$

Here we employed density functional theory (DFT) to estimate the stability of the $\mathrm{Pt}_{1 \mathrm{ML}}$ shell by studying the segregation of core $\mathrm{M}(\mathrm{M}=\mathrm{Cu}, \mathrm{Ru}, \mathrm{Rh}, \mathrm{Pd}, \mathrm{Ag}, \mathrm{Os}, \mathrm{Ir}$, $\mathrm{Au})$ under various environmental conditions. In principle, the segregation of core $\mathrm{M}$ should be prohibited to achieve the stability and activity of $\mathrm{Pt}_{1 \mathrm{ML}}$ shell. ${ }^{24}$ To simulate the core-shell conformation, we previously used near surface alloys (NSAs) with $\mathrm{Pt}_{1 \mathrm{ML}} / \mathrm{M}_{1 \mathrm{ML}} / \mathrm{Pt}(111)$ sandwich structure. ${ }^{25}$ Such model was used to describe the case with Pt core $-\mathrm{M}$ shell nanoparticles with size $>4 \mathrm{~nm}$, which displayed the bulk-like properties in term of both activity and stability. ${ }^{4,15,26}$ Due to the lower surface energy of $\mathrm{Pt}$ than $\mathrm{M}$, part of the core $\mathrm{Pt}$ atoms segregated to the surface and form a $\mathrm{Pt}_{1 \mathrm{ML}}$ shell, while the M shell atoms were buried in the subsurface. In this case, the surface 
strain in the $\mathrm{Pt}_{1 \mathrm{ML}}$ shell due to the mismatch between $\mathrm{Pt}$ and $\mathrm{M}$ lattice was not considered. ${ }^{27}$ In this paper, pseudomorphic surface alloys (PSAs) were considered to model the M core - Pt shell catalysts, where $1 \mathrm{ML}$ of Pt was deposited on the single crystal $M$ surfaces and formed $\mathrm{Pt}_{1 \mathrm{ML}} \mathrm{M}(111)$ for $\mathrm{M}=\mathrm{Cu}, \mathrm{Rh}, \mathrm{Pd}, \mathrm{Ir}, \mathrm{Ag}, \mathrm{Au}$ and $\mathrm{Pt}_{1 \mathrm{ML}} / \mathrm{M}(001)$ for $\mathrm{M}=\mathrm{Ru}$, Os. Different from NSAs, Pt adopted the lattice of M bulk in the case PSAs. In this way, the surface strain within the $\mathrm{Pt}_{1 \mathrm{ML}}$ shell introduced by the core metal was included. Such PSA model has been extensively used to describe the core-shell nanocatalysts in electrochemical applications. ${ }^{12,13,18-20,28-32}$

Our results showed that to achieve a stable $\mathrm{Pt}_{1 \mathrm{ML}}$ shell, different sets of candidate core $\mathrm{M}$ were identified depending on the type of solutions, perchloric acid $\left(\mathrm{HClO}_{4}\right)$, sulfuric acid $\left(\mathrm{H}_{2} \mathrm{SO}_{4}\right)$, phosphoric acid $\left(\mathrm{H}_{3} \mathrm{PO}_{4}\right)$ and alkaline solutions, as well as the undergoing reaction pathways for the ORR, direct or associative mechanisms. In addition, the segregation of a same core $\mathrm{M}$ under the same chemical environment can vary depending on the adopted conformation, PSA or NSA. Finally, our study highlights the importance of d-band center of core $\mathrm{M}(111)$ or (001) in determining the stability of $\mathrm{Pt}_{1 \mathrm{ML}}$ shell.

\section{Methods and models}

Similar to our previous study, ${ }^{25}$ spin-polarized DFT calculations were performed using the CASTEP code. ${ }^{33,34}$ The generalized gradient approximation (GGA) ${ }^{35}$ with the revised Perdew-Burke-Ernzerhof functional $(\mathrm{RPBE})^{36}$ was used to describe the 
exchange and correlation potential. The cutoff energy for the plane-wave basis set was set to $520 \mathrm{eV}$ in all calculations. The Monkhorst-Pack ${ }^{37}$ mesh k-points $(9 \times 9 \times 9)$ and $(5 \times 5 \times 1)$ were used for the bulk and slab calculations, respectively. A convergence accuracy of $1.0 \times 10^{-6} \mathrm{eV} /$ atom was set for the self-consistent field (SCF) calculation. In DFT calculations, the core shell alloys, $\mathrm{Pt}_{\mathrm{ML}} \mathrm{M}(111)(\mathrm{M}=\mathrm{Cu}, \mathrm{Ru}, \mathrm{Rh}$, $\mathrm{Pd}, \mathrm{Ag}, \mathrm{Os}, \mathrm{Ir}, \mathrm{Au}$ ) were modeled using a five-layer slab and a $2 \times 2$ array in each layer (Figure 1a). In addition, the gradual segregation of core $M$ from the second layer in the subsurface to the surface layer by exchanging position with nearby Pt atoms in the surface, via $\mathrm{Pt}_{1 \mathrm{ML}} \mathrm{M}(111)$ [or $(001)$ for $\mathrm{Os}$ and $\left.\mathrm{Ru}\right]$ to $\mathrm{Pt}_{0.75 \mathrm{ML}} \mathrm{M}_{0.25 \mathrm{ML}} / \mathrm{Pt}_{0.25 \mathrm{ML}} \mathrm{M}_{0.75 \mathrm{ML}} / \mathrm{M}(111)$ or (001), $\mathrm{Pt}_{0.5 \mathrm{ML}} \mathrm{M}_{0.5 \mathrm{ML}} / \mathrm{Pt}_{0.5 \mathrm{ML}} \mathrm{M}_{0.5 \mathrm{ML}} / \mathrm{M}(111)$ or $(001), \quad \mathrm{Pt}_{0.25 \mathrm{ML}} \mathrm{M}_{0.75 \mathrm{ML}} / \mathrm{Pt}_{0.75 \mathrm{ML}} \mathrm{M}_{0.25 \mathrm{ML}} / \mathrm{M}(111)$ or $(001)$ and eventually $\mathrm{M}_{1 \mathrm{ML}} / \mathrm{Pt}_{1 \mathrm{ML}} / \mathrm{M}(111)$ or $(001)$, was considered for both surfaces with and without adsorbates (Figure 1). A vacuum gap of $15 \AA$ in the z-direction was introduced to separate two subsequent slabs. The atoms in the top three layers were allowed to relax, while the atoms on the remaining two layers were fixed at their ideal bulk positions.

The adsorption energies of $* \mathrm{O}, * \mathrm{OH}, * \mathrm{OOH}, * \mathrm{ClO}_{4},{ }^{*} \mathrm{SO}_{4}$ and $* \mathrm{PO}_{4}$ at different adsorption sites were examined at the coverage of $0.25 \mathrm{ML}$. The effect of coverage was not considered assuming that the difference from one system to the next under the same conditions was similar. This is our interest in the present study. The segregation energy under vacuum conditions is calculated according to : 


$$
\Delta \mathrm{E}_{\mathrm{segr}}(i)=\mathrm{E}_{P t_{(1-i) M L} M_{i M L} / P t_{i M L} M_{(1-i) M L} / M(111)}-\mathrm{E}_{P t_{1 M L} / M_{1 M L} / M(111)} .
$$

The segregation energy under the ORR conditions is calculated as

$$
\Delta \mathrm{E}_{\text {segr }}(i)=\mathrm{E}_{a d s+P t_{(1-i) M L} M_{i M L} / P t_{i M L} M_{(1-i) M L} / \mathrm{M}(111)}-\mathrm{E}_{a d s+P t_{1 M L} / M(111)}, \quad \text { (eq. 2) }
$$

where $\mathrm{E}$ is the total energy of the slabs, and " $a d s$ " represents an adsorbed species on the surface. " $i$ " is the coverage (ML) of $\mathrm{M}$ atom in the surface layer $(0 \leq i \leq 1)$. $\Delta \mathrm{E}_{\text {segr }}(i)$ stands for the energy cost for core $\mathrm{M}$ atoms segregating from subsurface to surface. The binding energy of surface $\mathrm{M}_{4}$ layer $\left(\Delta \mathrm{E}_{b}\right)$ on a $\mathrm{M}_{4} / \mathrm{Pt}_{4} / \mathrm{M}$ surface is defined as

$\Delta \mathrm{E}_{\mathrm{b}}=\mathrm{E}_{M_{1 M L} / P t_{1 M L} / \mathrm{M}(111)}-\mathrm{E}_{P t_{1 M L} / M(111)}-n \mathrm{E}_{M}$,

where $\mathrm{E}_{M_{1 M L} / P t_{1 M L} / \mathrm{M}(111)}, \mathrm{E}_{P t_{1 M L} / M(111)}$ and $\mathrm{E}_{M}$ represents the total energy of a $\mathrm{M}_{1 \mathrm{ML}} / \mathrm{Pt}_{1 \mathrm{ML}} / \mathrm{M}(111)$ surface, the $\mathrm{Pt}_{1 \mathrm{ML}} / \mathrm{M}(111)$ surface formed by removing the surface $M$ layer, and a free $M$ atom in gas-phase, respectively. $n$ is the number of $M$ atoms in the surface.

\section{Results and discussions}

\subsection{Stability under vacuum conditions}

According to the calculated segregation energy, $\Delta \mathrm{E}_{\mathrm{segr}}$, under vacuum conditions $\mathrm{Pt}_{1 \mathrm{ML}} / \mathrm{M}(111)$ or $(001)(\mathrm{M}=\mathrm{Ru}, \mathrm{Rh}, \mathrm{Os}, \mathrm{Ir})$ in a PSA conformation is the most stable conformation, followed by $\mathrm{Pt}_{0.75 \mathrm{ML}} \mathrm{M}_{0.25 \mathrm{ML}} / \mathrm{Pt}_{0.25 \mathrm{ML}} \mathrm{M}_{0.75 \mathrm{ML}} / \mathrm{M}(111)$ or $(001)>$ $\mathrm{Pt}_{0.5 \mathrm{ML}} \mathrm{M}_{0.5 \mathrm{ML}} / \mathrm{Pt}_{0.5 \mathrm{ML}} \mathrm{M}_{0.5 \mathrm{ML}} / \mathrm{M}(111)$ or $(001)>\mathrm{Pt}_{0.25 \mathrm{ML}} \mathrm{M}_{0.75 \mathrm{ML}} / \mathrm{Pt}_{0.75 \mathrm{ML}} \mathrm{M}_{0.25 \mathrm{ML}} / \mathrm{M}(111)$ or $(001)>\mathrm{M}_{1 \mathrm{ML}} / \mathrm{Pt}_{1 \mathrm{ML}} / \mathrm{M}(111)$ or $(001)$ in a decreasing sequence (Figure 2 and Table 
$\mathrm{S}^{38}$ ). That is, $\mathrm{Pt}$ energetically prefers to form a $\mathrm{Pt}_{1 \mathrm{ML}}$ shell, while core $\mathrm{M}$ favors to stay in the core. The segregation of core $\mathrm{M}$ to the shell is endothermic, which increases with the increasing amount of $\mathrm{M}$ in the shell. The opposite trend is observed for $\mathrm{M}=\mathrm{Ag}, \mathrm{Au}$ (Figure 2) as observed for the corresponding NSAs, which is attributed to the lower surface energy of $\mathrm{Ag}$ or $\mathrm{Au}$ than that with a Pt (Table S2 $\left.{ }^{38}\right){ }^{25}$ In addition, the magnitude of $\Delta \mathrm{E}_{\text {segr }}$ depends on the electronic difference between core $\mathrm{M}$ and $\mathrm{Pt}$. In general, the core $\mathrm{M}$ that locates further away from $\mathrm{Pt}$ (e.g. $\mathrm{Ru}$ ) in a periodic table affect $\Delta \mathrm{E}_{\text {segr }}$ or the stability of the $\mathrm{Pt}_{1 \mathrm{ML}}$ shell more strongly than those that is near Pt (e.g. Pd).

Using $\mathrm{Cu}(111)$ as core is the only case in our study, where the segregation energy can be both positive and negative depending on the number of $\mathrm{Cu}$ atoms in the shell (Figure 2, Table $\mathrm{S}^{38}$ ). Balbuena, et al. also predicted the segregation of $\mathrm{Cu}$ to the $\mathrm{Pt} / \mathrm{Cu}(111)$ surface both under vacuum and in interaction with oxygen. ${ }^{13}$ This is different from the case of NSAs, where only positive segregation energy is observed. ${ }^{25}$ Indeed, Chorkendoff and coworkers found that only $\mathrm{Pt}_{1 \mathrm{ML}} / \mathrm{Cu}_{1 \mathrm{ML}} / \mathrm{Pt}(111)$ conformation displayed an 8 -fold improvement in the ORR activity of $\operatorname{Pt}(111) .{ }^{39}$ Although the partial segregation of $\mathrm{Cu}$ is thermodynamically favorable, the corresponding reaction energy is less than $0.4 \mathrm{eV}$. Given that, such small driving force for core $\mathrm{Cu}$ segregating to the shell may not be feasible under the operating temperature of fuel cells due to the kinetic obstacles, which may only take place via the surface defects. ${ }^{15}$ 
To achieve both the activity and stability of core-shell catalysts for the ORR in fuel cells, the formation of $\mathrm{Pt}_{1 \mathrm{ML}}$ shell is preferred. Following the method employed to describe the NSAs, ${ }^{25}$ we scaled the stability of PSAs using the lowest segregation energy, which represents the lowest energy cost to allow core $M$ to segregate and therefore destabilize the $\mathrm{Pt}_{1 \mathrm{ML}}$ shell. As shown in Figure 3, under vacuum conditions $\mathrm{Ru}, \mathrm{Rh}, \mathrm{Pd}$, Os, and Ir can be considered as good candidates for the core, where the color index (blue to white) indicates that the formation of $\mathrm{Pt}_{1 \mathrm{ML}}$ shell is either exothermic or at least thermoneutral. For $\mathrm{M}=\mathrm{Ag}, \mathrm{Au}$, the $\mathrm{Pt}_{1 \mathrm{ML}} / \mathrm{M}(111)$ has been found active for the ORR. ${ }^{24}$ However, it is not as stable as the formation of $\mathrm{M}_{1 \mathrm{ML}} / \mathrm{Pt}_{1 \mathrm{ML}} / \mathrm{M}(111)$, which destabilizes the $\mathrm{Pt}_{1 \mathrm{ML}}$ shell and leads to the decrease in activity. ${ }^{40}$ Therefore, Ag and Au cores will not be considered for our further study in the following. Similar results were observed in the case of NSAs. ${ }^{25}$ The only difference between PSAs and NSAs is for $\mathrm{M}=\mathrm{Cu} . \mathrm{Pt}_{1 \mathrm{ML}} / \mathrm{Cu}_{1 \mathrm{ML}} / \mathrm{Pt}(111)$ in the NSA conformation displays higher stability under vacuum conditions than those with $\mathrm{Cu}$ partially or fully segregated to the shell; however in the form of PSA, the partial segregation of $\mathrm{Cu}$ is more favorable than that of $\mathrm{Pt}_{1 \mathrm{ML}} / \mathrm{Cu}(111)$ (Figure 3). Since $\mathrm{Pt}$ partially stays on the surface, $\mathrm{Cu}$ core will be considered for the further study.

\subsection{Understanding the trend}

The variation trend of segregation energy, $\Delta \mathrm{E}_{\mathrm{segr}}$, with the species of core $\mathrm{M}$ (Figure 2) can be well described by d-band center $\left(E_{d}\right)^{8,32,41}$ of core $M$. In the case that core $\mathrm{M}$ segregates to form a $\mathrm{M}_{1 \mathrm{ML}} / \mathrm{Pt}_{1 \mathrm{ML}} \mathrm{M}(111)$ or (001), for example, the 
corresponding segregation energy, $\Delta \mathrm{E}_{\mathrm{segr}}$, increases exponentially with the $\mathrm{E}_{\mathrm{d}}$ of $M_{1 M L}$ shell shifts toward the Fermi-level (Figure $4 a$ ). When the $E_{d}$ of $M$ shifts upwards and approaches to that of $\mathrm{Pt}(\mathrm{M}=\mathrm{Au}, \mathrm{Ag}), \Delta \mathrm{E}_{\mathrm{segr}}$ becomes less negative (Figure $4 \mathrm{a}$, Table $\mathrm{S}^{38}$ ). That is, thermodynamically it is favorable for core $\mathrm{M}$ to segregate under vacuum conditions. In the case that the $\mathrm{E}_{\mathrm{d}}$ of $\mathrm{M}$ is close to that of $\mathrm{Pt}$, the formation of $\mathrm{M}_{1 \mathrm{ML}} / \mathrm{Pt}_{1 \mathrm{ML}} / \mathrm{M}(111)(\mathrm{M}=\mathrm{Pd})$ shows the least variation in $\Delta \mathrm{E}_{\mathrm{segr}}(\leq$ $0.05 \mathrm{eV})$, which is greatly increased by using core $\mathrm{M}(\mathrm{M}=\mathrm{Ru}, \mathrm{Rh}, \mathrm{Ir}, \mathrm{Os})$ with the $\mathrm{E}_{\mathrm{d}}$ lying higher than that of Pt. In both cases, the segregation of core $\mathrm{M}$ is likely to be hindered and the formation of the $\mathrm{Pt}_{1 \mathrm{ML}}$ shell should be preferred.

The d-band center of $\mathrm{M}(111)$ or $\mathrm{M}(001)$ determines the stability of $\mathrm{Pt}_{1 \mathrm{ML}}$ shell via the interplay between the surface energy of $M$ and binding property of $M$ with Pt or the core-shell interaction, which can vary depending on the strain introduced by the lattice mismatch between Pt and M. Upon the full segregation of core M (Figure 4a), there is no strain on the surface of $\mathrm{M}_{1 \mathrm{ML}} / \mathrm{Pt}_{1 \mathrm{ML}} / \mathrm{M}(111)$ or (001). For $\mathrm{M}=\mathrm{Ru}, \mathrm{Rh}, \mathrm{Pd}$, $\mathrm{Ag}, \mathrm{Os}, \mathrm{Ir}, \mathrm{Au}$, the control of $\mathrm{E}_{\mathrm{d}}$ to the variation in segregation can be simply estimated according to the $\mathrm{E}_{\mathrm{d}}$ of $\mathrm{M}(111)$ or (001) bulk surface. With the strain in the Pt-Pt bond is less than 5\% (Table $\mathrm{S} 2^{38}$ ), the d-band of segregated $\mathrm{M}_{\mathrm{ML}}$ shell and therefore the corresponding surface energy is close to that of $\mathrm{M}(111)$ or (001) bulk surfaces (Table $\mathrm{S}^{38}$ ). The higher the d-band center and surface energy of $\mathrm{M}(111)$ or (001), the higher the segregation energy for the core $\mathrm{M}$ and therefore the more stable the $\mathrm{P}_{1 \mathrm{ML}}$ shell is. In this case, the shell-core interaction does not play a major role. As 
shown in Figure $4 b$, the interaction between $\mathrm{M}_{1 \mathrm{ML}}$ shell and $\mathrm{Pt}_{1 \mathrm{ML}} / \mathrm{M}(111)$ or $(001)$ core shows a decreasing with the increasing in $E_{d}$ of $M$, which is opposite to that seen for the corresponding segregation energy (Figure 4a).

The strain effect can play an important role when the contraction or stretch in the lattice is significant. For the systems studied, this is only the case for $\mathrm{Pt}_{1 \mathrm{ML}} / \mathrm{Cu}(111)$, where the biggest difference in lattice between $\mathrm{Pt}$ and $\mathrm{Cu}\left(\right.$ Table $\mathrm{S} 2^{38}$ ) introduces the highest contraction in Pt-Pt bond $\left(\mathrm{d}_{\mathrm{Cu}-\mathrm{Cu}} / \mathrm{d}_{\mathrm{Pt}-\mathrm{Pt}}-1,-8.8 \%\right) .{ }^{38}$ As a consequence, $\mathrm{Pt}$ is deactivated due to the down-shifted d-band center $\left(E_{d}=-2.69 \mathrm{eV}\right)\left(\right.$ Table S3 $\left.{ }^{38}\right)$. Consequently, the interaction between $\mathrm{Pt}$ and $\mathrm{Cu}$ is too weak to hold the $\mathrm{Pt}_{1 \mathrm{ML}}$ shell. The stability of $\mathrm{Pt}_{1 \mathrm{ML}}$ shell can be promoted by intermixing $\mathrm{Pt}$ with $\mathrm{Cu}$, which releases the surface stress to $-6.4 \%,-4.3 \%$ and $-2.1 \%$ respectively with the increasing number of $\mathrm{Cu}$ in the shell going from 1 to 3 (Table $\mathrm{S} 1^{38}$ ); yet the stabilization is less significant. Eventually, with the complete release of the stress in the shell, $\mathrm{Cu}_{1 \mathrm{ML}} / \mathrm{Pt}_{1 \mathrm{ML}} / \mathrm{Cu}(111)$ is less stable than $\mathrm{Pt}_{1 \mathrm{ML}} / \mathrm{Cu}(111)$ (Figure 2), though $\mathrm{Cu}(111)$ displays lower surface energy than $\operatorname{Pt}(111)$ (Figure S2). ${ }^{38}$ That is, $E_{\mathrm{d}}$ and surface energy for $\mathrm{Cu}(111)$ in this case cannot explain the trend in segregation energy; instead the core-shell interaction is found to play a dominant role. Due to strongly stressed PtPt bond, the core-shell interaction for $\mathrm{Cu}_{1 \mathrm{ML}} / \mathrm{Pt}_{1 \mathrm{ML}} / \mathrm{Cu}(111)$ is significantly weakened. It shifts the $\mathrm{E}_{\mathrm{d}}$ of $\mathrm{Cu}_{1 \mathrm{ML}}$ shell towards the Fermi level $\left(\mathrm{E}_{\mathrm{d}}=1.96 \mathrm{eV}\right)$, which is higher than that of $\mathrm{Pt}(111)$. Therefore, the higher surface energy for $\mathrm{Cu}_{1 \mathrm{ML}} / \mathrm{Pt}_{1 \mathrm{ML}} / \mathrm{Cu}(111)$ is observed (Figure 4), while the $\mathrm{E}_{\mathrm{d}}$ of $\mathrm{Cu}(111)^{8,32,41}$ and therefore the surface energy 
(Table $\mathrm{S}^{38}$ ) is lower than $\mathrm{Pt}(111)$ (Table $\mathrm{S} 2^{38}$ ). Decreasing the amount of $\mathrm{Cu}$ in the shell effectively reduces the surface energy and $\Delta E_{\text {segr }}$ increases negatively (Figure 2).

Overall, the stability of $\mathrm{Pt}_{1 \mathrm{ML}}$ shell is associated with the $\mathrm{E}_{\mathrm{d}}$ of core $\mathrm{M}$. When the shell strain introduced by the core is relatively small, one can simply use the $E_{d}$ of $\mathrm{M}(111)$ or (001) bulk surface to estimate the stability of $\mathrm{Pt}_{1 \mathrm{ML}}$ shell. To assure the stability of $\mathrm{Pt}_{1 \mathrm{ML}}$ shell in vacuum, the core metals should be chosen among those with the $E_{d}$ and therefore the surface energy higher than Pt, e.g. $\mathrm{Ru}, \mathrm{Rh}, \mathrm{Pd}, \mathrm{Os}$, and Ir. When the strain is strong, e.g. $\mathrm{Pt}_{1 \mathrm{ML}} / \mathrm{Cu}(111)$ and $\mathrm{Cu}_{1 \mathrm{ML}} / \mathrm{Pt}_{1 \mathrm{ML}} / \mathrm{Cu}(111)$, the $\mathrm{E}_{\mathrm{d}}$ of $\mathrm{Pt}$ or the $\mathrm{Cu}_{1 \mathrm{ML}}$ shell can be very different from the bulk surfaces. In this case, the stability of $\mathrm{Pt}_{1 \mathrm{ML}}$ shell likely depends on the core-shell interaction.

\subsection{Stability under acidic and alkaline solutions.}

The electrochemical reaction occurs at the electrodes under solutions, which is typically either acidic or alkaline. According to our previous study of NSAs, ${ }^{25}$ we estimate the solution effect by recalculating $\Delta E_{\text {segr }}$ in presence of anions from the solution adsorbed on the surface (Figure 5). Accordingly, to describe the effect of acid solution, $\mathrm{HClO}_{4}, \mathrm{H}_{2} \mathrm{SO}_{4}$ and $\mathrm{H}_{3} \mathrm{PO}_{4}$, the adsorbed $* \mathrm{ClO}_{4}, * \mathrm{SO}_{4}$ and $* \mathrm{PO}_{4}$ were considered. The effect of alkaline was simulated by $* \mathrm{OH}$ adsorbed on the surfaces. The adsorption of anions on metal electrodes has been one of the major topics in surface electrochemistry. It has been realized for a long time that these specifically adsorbing anions have an important effect in a number of electrochemical reactions, including the stability of catalysts. ${ }^{42,43}$ Our calculations started with the most stable 
surface conformation, and the possibility of sequentially pulling core $\mathrm{M}$ to the shell and forming strong bonds with the adsorbates was also included (Figure 5).

Similar to the case of NSAs, ${ }^{25}$ the tetrahedral $* \mathrm{ClO}_{4}$ adopts a $\eta^{3}$ conformation via three oxygen atoms at Pt atop sites (Figure 5). Compared to the results under vacuum conditions, ${ }^{*} \mathrm{ClO}_{4}$ induces the decreasing of $\Delta \mathrm{E}_{\mathrm{segr}}$ (Figure 6a, Table $\mathrm{S}^{38}$ ). Again, big changes in $\Delta \mathrm{E}_{\text {segr }}$ are observed when the $\mathrm{E}_{\mathrm{d}}$ of core $\mathrm{M}(111)$ or $(001)$ $(\mathrm{M}=\mathrm{Ru}, \mathrm{Os}, \mathrm{Ir})$ is away from that of $\operatorname{Pt}(111)$, while the variation is relatively small for $\mathrm{M}(111)(\mathrm{M}=\mathrm{Rh}, \mathrm{Pd})$ with the $\mathrm{E}_{\mathrm{d}}$ close to that of Pt (Figure 6a). Among the systems studied, the case with $\mathrm{Ru}(001)$ core shows the most significant changes in $\Delta \mathrm{E}_{\text {segr }}$ going from $2.76 \mathrm{eV}$ under the vacuum conditions to $1.49 \mathrm{eV}$ due to the presence of ${ }^{*} \mathrm{ClO}_{4}$. This is due to the fact that $\mathrm{Ru}$ has the highest-lying $\mathrm{E}_{\mathrm{d}}$ than the other core $\mathrm{M}$ studied (Figure 3, Table $\mathrm{S}^{38}$ ), which allows Ru to provide a high binding to the cation and therefore a big driving force for Ru segregating to the surface. However, it is not strong enough to compensate the overall cost for $\mathrm{Ru}$ segregation and $\Delta \mathrm{E}_{\text {segr }}$ remains positive. Similar situation is also observed for PtOs and PtIr. In contrast, for $\mathrm{Pt}_{1 \mathrm{ML}} / \mathrm{M}(111)(\mathrm{M}=\mathrm{Cu}, \mathrm{Rh}, \mathrm{Pd})$ such driving force is capable to overcome the endothermicity and $\Delta \mathrm{E}_{\text {segr }}$ decreases to negative values (Figure 6a, Table $\mathrm{S} 4^{38}$ ). Yet, the magnitude is very small $(>-0.4 \mathrm{eV})$ with $\mathrm{M}=\mathrm{Rh}, \mathrm{Pd}$ due to the close $\mathrm{E}_{\mathrm{d}}$ and therefore the binding activity among Rh, Pd and Pt (Figure 4, Table S3 ${ }^{38}$ ). Therefore, the driving force induced by the difference in binding energy between $\mathrm{Pt}_{-} \mathrm{ClO}_{4}$ and

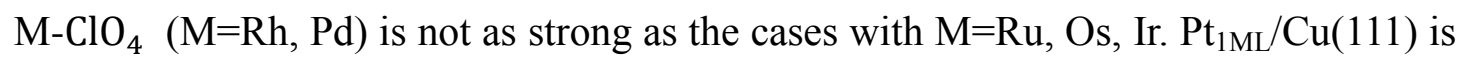


an exceptional case, where the $\mathrm{Cu}$ atoms are distorted from the lattice position on interacting with $* \mathrm{ClO}_{4}$ more significantly than the other systems (Figure 5). It results in the activation of $\mathrm{Cu}$ and the decreased $\Delta \mathrm{E}_{\text {segr }}$ to around $-1 \mathrm{eV}$ (Figure 6a, Table $\mathrm{S} 4^{38}$ ). Here, we note that increasing the size of unit cell can help in alleviating the distortion. Even though, the results using $2 \times 2$ unit cell on the different behavior of $\mathrm{PtCu}$ from PtM $(\mathrm{M}=\mathrm{Ru}, \mathrm{Rh}, \mathrm{Pd}, \mathrm{Os}, \mathrm{Ir})$ are still valid, which is the interest of our current study.

The tetrahedral $* \mathrm{SO}_{4}$ and $* \mathrm{PO}_{4}$ adopt the same conformation as $* \mathrm{ClO}_{4}$ on metal surfaces (Figure S1, Figure S2) ${ }^{38}$ in consistent with the previous observations on the NSAs. ${ }^{25}$ In addition, $\Delta \mathrm{E}_{\text {segr }}$ is decreased further more when changing the solution from $\mathrm{HClO}_{4}$ to $\mathrm{H}_{2} \mathrm{SO}_{4}$ and $\mathrm{H}_{3} \mathrm{PO}_{4}$ (Figure 6a-c). The considerable effects of $\mathrm{H}_{2} \mathrm{SO}_{4}{ }^{44}$ and $\mathrm{H}_{3} \mathrm{PO}_{4}$ on the crystal structure of Pt catalysts has been observed experimentally in contrast to $\mathrm{HClO}_{4} \cdot{ }^{45}$ The difference depends on the binding activity of the anions. Although in $H_{2} \mathrm{SO}_{4} \Delta \mathrm{E}_{\text {segr }}$ stays positive for $\mathrm{Pt}_{1 \mathrm{ML}} / \mathrm{Ru}(001)$, $\mathrm{Pt}_{1 \mathrm{ML}} / \mathrm{Os}(001)$ and $\mathrm{Pt}_{1 \mathrm{ML}} / \operatorname{Ir}(111)$ as that in $\mathrm{HClO}_{4}$, the magnitude is decreased significantly due to the stronger $* \mathrm{SO}_{4}$ species than $* \mathrm{ClO}_{4}$ (Figure $6 \mathrm{~b}$, Table $\mathrm{S}^{38}$ ). On the contrary, for $\mathrm{Pt}_{1 \mathrm{ML}} / \mathrm{Pd}(111)$ and $\mathrm{Pt}_{1 \mathrm{ML}} / \mathrm{Rh}(111) \Delta \mathrm{E}_{\text {segr }}$ stays more or less the same as that in either solutions $(>-0.4 \mathrm{eV})$ due to the close binding properties of core $\mathrm{M}$ to $\mathrm{Pt}$, as addressed above based on the d-band center (Figure 3). The decreased $\Delta \mathrm{E}_{\text {segr }}$ is also observed for $\mathrm{Pt}_{1 \mathrm{ML}} / \mathrm{Cu}(111)$ in $\mathrm{H}_{2} \mathrm{SO}_{4}$ compared with that in $\mathrm{HClO}_{4}$ (Figure 6a,b). Again this is attributed to the structural changes of $\mathrm{Cu}$ interacted with $* \mathrm{SO}_{4}$ 
(Figure $\mathrm{S}^{38}$ ), which is more significant than the other systems. Therefore, to stabilize the $\mathrm{Pt}_{1 \mathrm{ML}}$ shell in $\mathrm{H}_{2} \mathrm{SO}_{4}$, the core $\mathrm{M}$ should be chosen among $\mathrm{Ru}, \mathrm{Os}, \mathrm{Ir}, \mathrm{Rh}$, and $\mathrm{Pd}$. $* \mathrm{PO}_{4}$ promotes the segregation of core $\mathrm{M}$ more strongly than ${ }^{*} \mathrm{SO}_{4}$ and ${ }^{*} \mathrm{ClO}_{4}$. As shown in Figure 6c and Table $\mathrm{S}^{38}$ only $\mathrm{Pt}_{1 \mathrm{ML}} / \mathrm{Os}(001)$ and $\mathrm{Pt}_{1 \mathrm{ML}} / \mathrm{Ir}(111)$ are able to keep $\Delta \mathrm{E}_{\text {segr }}$ positive and maintain the $\mathrm{Pt}_{1 \mathrm{ML}}$ shell. For $\mathrm{Pt}_{1 \mathrm{ML}} / \mathrm{Ru}(001), \Delta \mathrm{E}_{\text {segr }}$ is negative, though the magnitude is small $(>-0.25 \mathrm{eV})$. Again $\Delta \mathrm{E}_{\mathrm{segr}}$ for $\mathrm{Pt}_{1 \mathrm{ML}} / \mathrm{Pd}(111)$ and $\mathrm{Pt}_{1 \mathrm{ML}} / \mathrm{Rh}(111)$ is not sensitive to the changing of the solutions and stays as slightly negative $(>-0.4 \mathrm{eV})$. On $\mathrm{Pt}_{1 \mathrm{ML}} / \mathrm{Cu}(111),{ }^{*} \mathrm{PO}_{4}$ shows stronger effects than $* \mathrm{SO}_{4}$ and $* \mathrm{ClO}_{4}$ on decreasing $\Delta \mathrm{E}_{\mathrm{segr}}$ via the structural distortion of $\mathrm{Cu}$ on the surface (Figure S2 ${ }^{38}$ ), which enables the segregation of $\mathrm{Cu}$ more thermodynamically favorable (Figure 6c, Table $\mathrm{S}^{38}$ ). Accordingly, in $\mathrm{H}_{3} \mathrm{PO}_{4}$ solution Os, Ir as well as $\mathrm{Ru}, \mathrm{Rh}$ and $\mathrm{Pd}$ can be considered as the cores to stabilize the $\mathrm{Pt}_{1 \mathrm{ML}}$ shell.

Compared to the acid solutions, the effect of alkaline solutions on the surface segregation is less effective. The preferential adsorption sites vary from atop, bridge to hollow depend on the amount of $\mathrm{M}$ on the surface (Figure 7). Figure $6 \mathrm{~d}$ and Table $\mathrm{S} 7^{38}$ show that $* \mathrm{OH}$ also leads to the lowered $\Delta \mathrm{E}_{\text {segr }}$; yet the effect is not as strong as that of $* \mathrm{SO}_{4} * \mathrm{PO}_{4}$, but rather as weakly as that of $* \mathrm{ClO}_{4}$ (Figure 6). Therefore, in alkaline solutions, the same core metals ( $\mathrm{Ru}, \mathrm{Rh}, \mathrm{Pd}, \mathrm{Os}$, and Ir) as those in $\mathrm{HClO}_{4}$ are predicated to stabilize the $\mathrm{Pt}_{1 \mathrm{ML}}$ shell.

As shown in Figure 3, using $\mathrm{Ru}, \mathrm{Os}, \mathrm{Ir}, \mathrm{Pd}$, and $\mathrm{Rh}$ as core is able to stabilize the $\mathrm{Pt}_{1 \mathrm{ML}}$ shell in acid and alkaline solutions. Depending on the binding strength of anions 
with the surface, the stability of $\mathrm{Pt}_{1 \mathrm{ML}} \mathrm{M}(111)$ or $(001)(\mathrm{M}=\mathrm{Ru}$, Os, Ir) varies significantly. The strong $* \mathrm{PO}_{4}$, are likely to decrease $\Delta \mathrm{E}_{\mathrm{segr}}(i)$ and destabilize the $\mathrm{Pt}_{\mathrm{ML}}$ shell more strongly than the weak $* \mathrm{ClO}_{4}$ and $* \mathrm{OH}$ (Figure 3 ). In contrast, $\mathrm{Pt}_{1 \mathrm{ML}} / \mathrm{Rh}(111)$ and $\mathrm{Pt}_{1 \mathrm{ML}} / \mathrm{Pd}(111)$ show less sensitivity to the variation in solution and the corresponding $\Delta \mathrm{E}_{\text {segr }}$ under all environments stays roughly thermoneutral (Figure 3). Thus, the segregation may not be feasible under operating temperature of fuel cells due to the kinetics obstacles.

Combining with our previous study of NSAs, ${ }^{25}$ we predict that $\mathrm{Ru}, \mathrm{Os}, \mathrm{Ir}, \mathrm{Rh}$, and $\mathrm{Pd}$ can be considered as alloying metals with $\mathrm{Pt}$ to stabilize the $\mathrm{Pt}_{1 \mathrm{ML}}$ shell in $\mathrm{HClO}_{4}, \mathrm{H}_{2} \mathrm{SO}_{4}$ and alkaline solutions, no matter whether the PSA or NSA conformations are adopted (Figure 3). However, one has to be careful with $\mathrm{H}_{3} \mathrm{PO}_{4}$ solution, where in a NSA conformation only $\mathrm{Rh}, \mathrm{Pd}$ and $\mathrm{Ir}$ can be selected for alloying with Pt. This is associated with the surface strain introduced by $\mathrm{M}$ segregation in the case of NSAs. $\mathrm{Cu}$ is another case, where the structure makes big difference. By adopting a NSA conformation, the $\mathrm{Pt}_{1 \mathrm{ML}} / \mathrm{Cu}_{1 \mathrm{ML}} / \mathrm{Pt}(111)$ is stabile in $\mathrm{HClO}_{4}$ and alkaline solutions; however, in a PSA conformation, $\mathrm{Pt}_{1 \mathrm{ML}} / \mathrm{Cu}(111)$ cannot survive under any environment, where the huge contraction is introduced in the Pt-Pt bond by the $\mathrm{Cu}$ core.

\subsection{Stability under the ORR condition.}

It has been shown that the slow kinetics of the ORR on the cathode hinders the overall performance of low-temperature fuel cell. Therefore, we also studied the 
catalyst stability during the ORR. Following our previous study of the NSAs, ${ }^{25}$ we estimated the effect by considering the adsorption of reaction intermediates involved in the ORR, where the adsorptions of $* \mathrm{O},{ }^{*} \mathrm{OH}$ and ${ }^{*} \mathrm{OOH}$ were considered as the key intermediates involved in direct and/or associative pathways of the ORR. Since the ORR occurs by exposing to the air, the stability under the ORR can also be applied to that under air exposure.

*O interacts strongly with the surfaces by occupying the three-fold hollow sites. As shown in Figure $8 \mathrm{a}$ and Table $\mathrm{S} 8^{38}$, $* \mathrm{O}$ has a strong effect on the surface segregation as that of $* \mathrm{PO}_{4}$, where $\Delta \mathrm{E}_{\mathrm{segr}}$ is decreased effectively compared to the case in vacuum. Positive $\Delta \mathrm{E}_{\text {segr }}$ is only observed for $\mathrm{Pt}_{1 \mathrm{ML}} / \mathrm{Os}(001)$ and $\mathrm{Pt}_{1 \mathrm{ML}} / \operatorname{Ir}(111)$, and the slightly negative values are obtained for $\mathrm{Pt}_{1 \mathrm{ML}} / \mathrm{Rh}(001)$ and $\mathrm{Pt}_{1 \mathrm{ML}} / \mathrm{Pd}(111) . \mathrm{Pt}_{1 \mathrm{ML}} / \mathrm{Cu}(111)$ corresponds to a highly negative $\Delta E_{\mathrm{segr}}$. It means that under the $\mathrm{ORR}$ via $* \mathrm{O}$ intermediate the $\mathrm{Cu}$ core segregation is thermodynamically favorable and the formation of $\mathrm{Cu}$ oxides on the surface is likely to occur, in agreement with experiment. ${ }^{46}$

In contrast to ${ }^{*} \mathrm{O}$, the effect introduced by ${ }^{*} \mathrm{OH}$ is much less. For all the systems studied, $\Delta \mathrm{E}_{\text {segr }}$ is either positive or close to zero except $\mathrm{Pt}_{1 \mathrm{ML}} / \mathrm{Cu}(111$ ) (Figure 6d, Table $\mathrm{S}^{38}$ ). In the case of $* \mathrm{OOH}$, the situation is complicated (Figure $8 \mathrm{~b}$ and Table $\mathrm{S} 9^{38}$ ). Depending on the surface composition, it can be adsorbed either molecularly on a top position (Figure 9) or dissociatively (Figure $\mathrm{S} 3{ }^{38}$ ), where the ${ }^{*} \mathrm{OH}$ and ${ }^{*} \mathrm{O}$ fragments sit atop and hollow sites respectively. Our results show that the dissociative 
adsorption is energetically much more favorable than the molecular adsorption, which drives $\Delta \mathrm{E}_{\text {segr }}$ highly negative (Figure $8 \mathrm{~b}$ ). This is the case when using $\mathrm{Ru}$ and $\mathrm{Os}$ as core. $\mathrm{Cu}$ core also prefers to segregate and interact with ${ }^{*} \mathrm{OOH}$; however the adsorbate stays in a molecular form, but leads to a more significant surface distortion than the other cases (Figure 9). In the cases of using Pd and Rh cores, *OOH stays molecularly and $\Delta \mathrm{E}_{\text {segr }}$ remains close to zero. Ir is the only core, which displays highly positive $\Delta \mathrm{E}_{\text {segr }}$ and therefore highly stable $\mathrm{Pt}_{1 \mathrm{ML}}$ shell.

According to our calculations, if the ORR follows the direct pathway via *O and *OH, Os, Ir, Ru and Pd can be considered as core (Figure 4) to stabilize the $\mathrm{Pt}_{1 \mathrm{ML}}$ shell in a PSA conformation. Only Pd and Ir cores work well if the reaction undergoes the associative pathway via $* \mathrm{O},{ }^{*} \mathrm{OH}$ and ${ }^{*} \mathrm{OOH}$. When changing the structure to the NSA conformation, the candidate $\mathrm{M}$ can be very different depending on the reaction mechanism. ${ }^{25}$ In that case, $\mathrm{Pd}, \mathrm{Rh}$ and $\mathrm{Cu}$ are predicted as good candidates for the ORR via both pathways. Ir is only selected for the ORR via the direct pathway. Os and $\mathrm{Ru}$ are ruled out,

Overall, our calculations show that Pd and Ir are the only core metals among the systems studied here to keep the $\mathrm{Pt}_{1 \mathrm{ML}}$ shell intact as well as activity under vacuum, acid $\left(\mathrm{HClO}_{4}, \mathrm{H}_{2} \mathrm{SO}_{4}, \mathrm{H}_{3} \mathrm{PO}_{4}\right)$, alkaline solutions and the ORR via different pathways (Figure 3). This agrees well with the previous experiments, showing an increased stability of Pt shell when using Pd or Ir rather than Pt as core during the ORR in acid. ${ }^{15,47}$ Ir is one of the most stable metals and its activity towards the ORR 
is slightly enhanced by alloying with other transition metals. ${ }^{1,48}$ In addition, our calculations also show that $\mathrm{Ru}$ and Os should also be paid attention, which only fall during the ORR via the ${ }^{*} \mathrm{OOH}$ intermediate. Rh also works as long as the ORR does not undergo the pathway via ${ }^{*} \mathrm{O}$ intermediate. The destabilization of the $\mathrm{Pt}_{\mathrm{ML}}$ shell by core $\mathrm{Cu}$ under all conditions studied was observed.

The d-band center of $\mathrm{M}(111)$ or (001) bulk surface is found as an effective descriptor to explain the variation trend in $\Delta \mathrm{E}_{\mathrm{segr}}$ for all $\mathrm{Pt}_{\mathrm{ML}} / \mathrm{M}(111)$ or $(001)$ alloy surfaces studied. According to our results, the stability can be estimated simply according to the $\mathrm{E}_{\mathrm{d}}$. To stabilize the $\mathrm{Pt}_{1 \mathrm{ML}}$ shell under various conditions of the ORR, the core metal should adopt a $E_{d}$ close to that Pt. Compared to Pt, the $\mathrm{M}(\mathrm{Au}, \mathrm{Ag}$ ) cores with lower-lying $\mathrm{E}_{\mathrm{d}}$ display a lower surface energy and are likely to destabilize the Pt shell via preferential segregation in vacuum. Under various solutions and the ORR, similar segregation is likely to occur by using the active core $\mathrm{M}(\mathrm{Ru}, \mathrm{Rh}, \mathrm{Os})$, which adopt a higher-lying $\mathrm{E}_{\mathrm{d}}$ than $\mathrm{Pt}$ and therefore bind the adsorbates more strongly. By adopting a $\mathrm{E}_{\mathrm{d}}$ slightly higher than $\mathrm{Pt}, \mathrm{Pd}$ and $\mathrm{Ir}$ cores display a superior performance in stabilizing the $\mathrm{Pt}_{1 \mathrm{ML}}$ shell than the cores studied here, being able to provide a moderate property, active enough to hinder the segregation in vacuum and inert enough to prevent the segregation in interacting with an adsorbate under reaction conditions. Such general role cannot be applied to the case with huge strain introduced by the core, e.g. $\mathrm{Cu}$. On interacting with an adsorbate, the structural distortion occurs, which is more significant than the other systems. In this case, $\mathrm{Cu} \mathrm{E}_{\mathrm{d}}$ 
for bare surfaces cannot be used to describe the behavior of the alloy under the reaction conditions. According to the previous studies, the stability of Pt shell can be improved by using $\mathrm{PtCu}$ alloy as core to release the contraction, increasing the thickness of Pt shell from one monolayer to multiple layers, or varying $\mathrm{Pt}: \mathrm{Cu}$ ratio to form NSAs which can survive all the environments except $\mathrm{H}_{2} \mathrm{SO}_{4}$ and $\mathrm{H}_{3} \mathrm{PO}_{4}$ solutions. ${ }^{25,46}$ In addition, a recent study show that for a variety of Pt-based core-shell catalysts, the stability of Pt shell supported on a Pt alloy core can be promoted by introducing a subsurface Au layer. ${ }^{49}$

\section{Conclusion}

DFT was employed to study the stabilization of $\mathrm{Pt}_{1 \mathrm{ML}}$ shell by using various $\mathrm{M}$ cores $(\mathrm{M}=\mathrm{Cu}, \mathrm{Ru}, \mathrm{Rh}, \mathrm{Pd}, \mathrm{Ag}$; Os, Ir, $\mathrm{Au})$ under harsh ORR conditions in fuel cells on the basis of a PSA conformation, $\mathrm{Pt}_{1 \mathrm{ML}} \mathrm{M}(111)$ or $(001)$. To achieve a stable $\mathrm{Pt}_{1 \mathrm{ML}}$ shell, different sets of candidate $\mathrm{M}$ cores were identified depending on the conditions. $\mathrm{Pd}$ and $\mathrm{Ir}$ are the only two cores studied, being able to stabilize the $\mathrm{Pt}_{1 \mathrm{ML}}$ shell under vacuum conditions including acid $\left(\mathrm{HClO}_{4}, \mathrm{H}_{2} \mathrm{SO}_{4}, \mathrm{H}_{3} \mathrm{PO}_{4}\right)$ /alkaline solutions and the ORR via different pathways. In addition, Ru and Os should also be paid attention, which only fall during the ORR via the $* \mathrm{OOH}$ intermediate. Rh also works as long as the ORR does not undergo the pathway via *O intermediate.

Depending on the binding strength of anions from solution with the surface, the stability of $\mathrm{Pt}_{1 \mathrm{ML}}$ shell varies significantly when using $\mathrm{Ru}$, Os, and $\mathrm{Ir}$ as core; in 
contrast $\mathrm{Rh}$ and $\mathrm{Pd}$ cores show less sensitivity and the corresponding segregation energy under all studied environments is roughly thermoneutral. Thus the segregation may not be feasible under operating conditions of lower-temperature fuel cells due to the kinetics obstacles. The $\mathrm{Pt}_{1 \mathrm{ML}}$ shell is not stable under all environments with $\mathrm{Cu}$ core. The interaction of $\mathrm{Cu}$ with the anions from solutions and the reaction intermediates involved in the ORR can lead to more significant distortion of $\mathrm{Cu}$ than the other systems, which accelerates the dissolution of $\mathrm{Cu}$ on the surface and therefore deactivates the catalyst.

Finally, the d-band center of $\mathrm{M}(111)$ or (001) bulk surface is found as an effective descriptor for the shell stability of $\mathrm{Pt}_{1 \mathrm{ML}} / \mathrm{M}(111)$ or (001) alloy surfaces studied, when the strain introduced by the lattice mismatch between Pt and M is not significant. The superior performance of $\mathrm{Pd}$ and $\mathrm{Ir}$ in stabilizing the $\mathrm{Pt}_{1 \mathrm{ML}}$ shell is associated with by the adopted $\mathrm{E}_{\mathrm{d}}$ slightly higher than Pt. As a result, Pd and Ir are able to provide a moderate property, active enough to hinder the segregation in vacuum and inert enough to prevent the segregation in interacting with an adsorbate under reaction conditions. Our results not only provide the guidance to design coreshell catalysts with reasonable stability and activity, but also highlight the importance of interplay between the reaction environment and the catalysts structure in catalyst design.

\section{ACKNOWLEDGMENT}


P.L. would like to thank the funding from the US Department of Energy, Office of Science under Contract No. DE-SC0012704, and W.T.Z. would like to thank the funding from National Natural Science Foundation of China (No. 51372095). The DFT calculations utilized resources at the Center for Functional Nanomaterials (CFN), Brookhaven National Laboratory and High Performance Computing Center, Jilin University

\section{References}

1. K. A. Kuttiyiel, K. Sasaki, Y. Choi, D. Su, P. Liu and R. R. Adzic, Energy Environ. Sci. 5 (1), 5297-5304 (2012).

2. K. A. Kuttiyiel, K. Sasaki, Y. Choi, D. Su, P. Liu and R. R. Adzic, Nano Lett. 12 (12), 6266-6271 (2012).

3. K. Sasaki, H. Naohara, Y. Choi, Y. Cai, W.-F. Chen, P. Liu and R. R. Adzic, Nat. Commun. 3, 1115 (2012).

4. J. X. Wang, H. Inada, L. Wu, Y. Zhu, Y. Choi, P. Liu, W.-P. Zhou and R. R. Adzic, J. Am. Chem. Soc. 131 (47), 17298-17302 (2009).

5. H. Yang, Angew. Chem. Int. Ed. 50 (12), 2674-2676 (2011).

6. Y. Zhang, Y.-C. Hsieh, V. Volkov, D. Su, W. An, R. Si, Y. Zhu, P. Liu, J. X. Wang and R. R. Adzic, ACS Catal. 4 (3), 738-742 (2014).

7. M. P. Hyman and J. W. Medlin, J. Phys. Chem. C 111 (45), 1705217060 (2007).

8. J. K. Norskov, T. Bligaard, J. Rossmeisl and C. H. Christensen, Nat. Chem. 1 (1), 37-46 (2009).

9. V. Stamenkovic, B. S. Mun, K. J. Mayrhofer, P. N. Ross, N. M. Markovic, J. Rossmeisl, J. Greeley and J. K. Norskov, Angew. Chem. Int. Ed. 45 (18), 2897-2901 (2006).

10. H. Y. Su, X. H. Bao and W. X. Li, J. Chem. Phys. 128 (19) (2008).

11. V. R. Stamenkovic, B. S. Mun, K. J. J. Mayrhofer, P. N. Ross and N. M. Markovic, J. Am. Chem. Soc. 128 (27), 8813-8819 (2006).

12. J. Greeley, I. E. L. Stephens, A. S. Bondarenko, T. P. Johansson, H. A. Hansen, T. F. Jaramillo, RossmeislJ, ChorkendorffI and J. K. Nørskov, Nat. Chem. 1 (7), 552-556 (2009).

13. G. E. Ramirez-Caballero, Y. Ma, R. Callejas-Tovar and P. B. Balbuena, Phys. Chem. Chem. Phys. 12 (9), 2209-2218 (2010).

14. W. J. Xu, D. J. Cheng, M. Niu, X. H. Shao and W. C. Wang, 
Electrochimi. Acta 76, 440-445 (2012).

15. K. Sasaki, H. Naohara, Y. Cai, Y. M. Choi, P. Liu, M. B. Vukmirovic, J. X. Wang and R. R. Adzic, Angew. Chem. Int. Ed. 49 (46), 8602-8607 (2010).

16. J. Greeley and J. K. Nøskov, Electrochimi. Acta 52 (19), 5829-5836 (2007).

17. L.-L. Wang and D. D. Johnson, J J. Am. Chem. Soc. 131 (39), 1402314029 (2009).

18. G. E. Ramírez-Caballero and P. B. Balbuena, J. Phys. Chem. Lett. 1 (4), 724-728 (2010).

19. A. U. Nilekar and M. Mavrikakis, Surf. Sci. 602 (14), L89-L94 (2008).

20. A. Nilekar, Y. Xu, J. Zhang, M. Vukmirovic, K. Sasaki, R. Adzic and M. Mavrikakis, Top. Catal. 46 (3-4), 276-284 (2007).

21. L. Zhang, R. Iyyamperumal, D. F. Yancey, R. M. Crooks and G. Henkelman, ACS Nano 7 (10), 9168-9172 (2013).

22. J. Zhang, K. Sasaki, E. Sutter and R. R. Adzic, Science 315 (5809), 220-222 (2007).

23. J. X. Wang, C. Ma, Y. M. Choi, D. Su, Y. M. Zhu, P. Liu, R. Si, M. B. Vukmirovic, Y. Zhang and R. R. Adzic, J. Am. Chem. Soc. 133 (34), 1355113557 (2011).

24. J. Zhang, M. B. Vukmirovic, Y. Xu, M. Mavrikakis and R. R. Adzic, Angew. Chem. Int. Ed. 44, 2132-2135 (2005).

25. X. Zhang, S. Yu, W. Zheng and P. Liu, Phys. Chem. Chem. Phys. 16 (31), 16615-16622 (2014).

26. W. An and P. Liu, J. Phys. Chem. C 117 (31), 16144-16149 (2013).

27. M. D. Porosoff, W. Yu and J. G. Chen, J. Catal. 308 (0), 2-10 (2013).

28. M. Li, P. Liu and R. R. Adzic, J. Phys. Chem. Lett. 3 (23), 3480-3485 (2012).

29. P. Ferrin, A. U. Nilekar, J. Greeley, M. Mavrikakis and J. Rossmeisl, Surf. Sci. 602 (21), 3424-3431 (2008).

30. J. Zhang, M. B. Vukmirovic, K. Sasaki, A. U. Nilekar, M. Mavrikakis and R. R. Adzic, J. Am. Chem. Soc. 127 (36), 12480-12481 (2005).

31. A. L. Stottlemyer, P. Liu and J. G. Chen, J. Chem. Phys. 133 (10), 104702-104708 (2010).

32. S. Alayoglu, A. U. Nilekar, M. Mavrikakis and B. Eichhorn, Nat. Mater. 7 (4), 333-338 (2008).

33. M. D. Segall, P. J. D. Lindan, M. J. Probert, C. J. Pickard, P. J. Hasnip, S. J. Clark and M. C. Payne, J. Phys. Condens. Matter 14, 2717-2744 (2002).

34. S. J. Clark, M. D. Segall, C. J. Pickard, P. J. Hasnip, M. I. J. Probert, K. Refson and M. C. Payne, Z. Kristallogr. 220, 567-570 (2005).

35. J. P. Perdew, K. Burke and Y. Wang, Phys. Rev. B 54, 16533-16539 
(1996).

36. B. Hammer, L. B. Hansen and J. K. Norskov, Phys. Rev. B 59, 74137421 (1999).

37. H. J. -Monkhorst and J. D. Pack, Physical Review B 13 (12), 51885192 (1976).

38. See supplementary material at [URL will be inserted by AIP] for: 1 . segregation energies under various conditions, 3. d-band center, 4. geometries of surfaces in interaction with the anions.

39. I. E. L. Stephens, A. S. Bondarenko, F. J. Perez-Alonso, F. CalleVallejo, L. Bech, T. P. Johansson, A. K. Jepsen, R. Frydendal, B. P. Knudsen, J. Rossmeisl and I. Chorkendorff, J. Am. Chem. Soc. 133 (14), 5485-5491 (2011).

40. J. K. Nørskov, J. Rossmeisl, A. Logadottir, L. Lindqvist, J. Kitchin and T. Bligaard, J. Phys. Chem. B 108, 17886-17892 (2004).

41. B. Hammer and J. K. Nørskov, Adv. Catal. 45, 71 (2000).

42. D. V. Tripkovic, D. Strmcnik, D. van der Vliet, V. Stamenkovic and N. M. Markovic, Faraday Disc. 140 (0), 25-40 (2009).

43. Q. He, X. Yang, W. Chen, S. Mukerjee, B. Koel and S. Chen, Phys. Chem. Chem.Phys. 12 (39), 12544-12555 (2010).

44. F. El Kadiri, R. Faure and R. Durand, J. Electroanal. Chem. Inter. Electrochem. 301, 177-188 (1991).

45. A. Tanaka, K. Kanamura, A. R. and B. Cahan, presented at the Electrochemical Society Meeting, Montreal, 1990.

46. M. Oezaslan, F. Hasché and P. Strasser, Journal of The Electrochemical Society 159 (4), B444-B454 (2012).

47. S. J. Hwang, S. J. Yoo, T.-Y. Jeon, K.-S. Lee, T.-H. Lim, Y.-E. Sung and S.-K. Kim, Chem. Commun. 46 (44), 8401-8403 (2010).

48. J. Qiao, R. Lin, B. Li, J. Ma and J. Liu, Electrochimi. Acta 55 (28), 8490-8497 (2010).

49. C.-E. Kim, D.-H. Lim, J. H. Jang, H. J. Kim, S. P. Yoon, J. Han, S. W. Nam, S.-A. Hong, A. Soon and H. C. Ham, J. Chem. Phys. 142 (3), 034707 (2015). 


\section{Figure captions}

Figure 1 Optimized structures of core shell alloys surfaces: (a) $\mathrm{Pt}_{1 \mathrm{ML}} \mathrm{M}(111$ ); (b) $\mathrm{Pt}_{0.75 \mathrm{ML}} \mathrm{M}_{0.25 \mathrm{ML}} / \mathrm{Pt}_{0.25 \mathrm{ML}} \mathrm{M}_{0.75 \mathrm{ML}} / \mathrm{M}(111) ;$ (c) $\mathrm{Pt}_{0.5 \mathrm{ML}} \mathrm{M}_{0.5 \mathrm{ML}} / \mathrm{Pt}_{0.5 \mathrm{ML}} \mathrm{M}_{0.5 \mathrm{ML}} / \mathrm{M}(111) ;$ (d) $\mathrm{Pt}_{0.25 \mathrm{ML}} \mathrm{M}_{0.75 \mathrm{ML}} / \mathrm{Pt}_{0.75 \mathrm{ML}} \mathrm{M}_{0.25 \mathrm{ML}} / \mathrm{M}(111) ;(\mathrm{e}) \mathrm{M}_{1 \mathrm{ML}} / \mathrm{Pt}_{1 \mathrm{ML}} / \mathrm{M}(111) ;$ Blue: Pt; Brown: $\mathrm{M}$.

Figure 2 Calculated segregation energy, $\Delta \mathrm{E}_{\mathrm{segr}}$, as a funcation of number of $\mathrm{M}$ on the surface, $\mathrm{Pt}_{(1-\mathrm{i}) \mathrm{ML}} \mathrm{M}_{\mathrm{iML}} / \mathrm{Pt}_{\mathrm{iML}} \mathrm{M}_{(1-\mathrm{i}) \mathrm{ML}} / \mathrm{M}(111)$ or $(001)$.

Figure 3 Color-labeled stability of the $\mathrm{Pt}_{1 \mathrm{ML}}$ shell on various cores $\mathrm{M}(111)$ (or $\mathrm{M}(001)$ for hcp) surfaces under various conditions. Color index scales the stability from high (dark blue) to low (dark red) according to the lowest $\Delta \mathrm{E}_{\text {segr }}$ calculated using DFT.

Figure 4 Correlation between the calculated $\Delta \mathrm{E}_{\text {segr }}(1 \mathrm{ML})$ (Upper panel) or $\Delta \mathrm{E}_{b}$ (lower panel) under vacuum conditions and the $\mathrm{d}$ band center with respect to $\operatorname{Pt}(111)$, $E_{d^{-}} E_{d-P t}$ of $M$ on the surfaces of $\mathrm{M}_{1 \mathrm{ML}} / \mathrm{Pt}_{1 \mathrm{ML}} / \mathrm{M}(111)$ or $(001)$.

Figure 5 Optimized structures of $* \mathrm{ClO}_{4}$ on the core-shell alloy surfaces: (a) $\mathrm{Pt}_{1 \mathrm{ML}} / \mathrm{Cu}(111), \quad$ (b) $\quad \mathrm{Pt}_{0.75 \mathrm{ML}} \mathrm{Cu}_{0.25 \mathrm{ML}} / \mathrm{Pt}_{0.25 \mathrm{ML}} \mathrm{Cu}_{0.75 \mathrm{ML}} / \mathrm{Cu}(111)$,

$\mathrm{Pt}_{0.5 \mathrm{ML}} \mathrm{Cu}_{0.5 \mathrm{ML}} / \mathrm{Pt}_{0.5 \mathrm{ML}} \mathrm{Cu}_{0.5 \mathrm{ML}} / \mathrm{Cu}(111)$, (d) $\mathrm{Pt}_{0.25 \mathrm{ML}} \mathrm{Cu}_{0.75 \mathrm{ML}} / \mathrm{Pt}_{0.75 \mathrm{ML}} \mathrm{Cu}_{0.25 \mathrm{ML}} / \mathrm{Cu}(111)$. Blue: Pt; Brown: Cu; Red: O; Purple: $\mathrm{Cl}$.

Figure 6 Calculated segregation energy, $\Delta \mathrm{E}_{\mathrm{segr}}$, as a funcation of number of core $\mathrm{M}$ 
segregated to the surface, $\mathrm{Pt}_{(1-\mathrm{i}) \mathrm{ML}} \mathrm{M}_{\mathrm{iML}} / \mathrm{Pt}_{\mathrm{iML}} \mathrm{M}_{(1-\mathrm{i}) \mathrm{ML}} / \mathrm{M}$ (111) or (001), in $\mathrm{HClO}_{4}$, (a) $\mathrm{H}_{2} \mathrm{SO}_{4}$, (b) $\mathrm{H}_{3} \mathrm{PO}_{4}$ (c) and alkaline (d) solutions.

Figure 7 The optimized structures of $* \mathrm{OH}$ on the Pt/M(111) alloy surfaces: $(\mathrm{a}, \mathrm{b})$ $\mathrm{Pt}_{1 \mathrm{ML}} / \mathrm{Cu}(111), \quad$ (c) $\quad \mathrm{Pt}_{0.75 \mathrm{ML}} \mathrm{Cu}_{0.25 \mathrm{ML}} / \mathrm{Pt}_{0.25 \mathrm{ML}} \mathrm{Cu}_{0.75 \mathrm{ML}} / \mathrm{Cu}(111)$,

$\mathrm{Pt}_{0.5 \mathrm{ML}} \mathrm{Cu}_{0.5 \mathrm{ML}} / \mathrm{Pt}_{0.5 \mathrm{ML}} \mathrm{Cu}_{0.5 \mathrm{ML}} / \mathrm{Cu}(111)$, (e) $\mathrm{Pt}_{0.25 \mathrm{ML}} \mathrm{Cu}_{0.75 \mathrm{ML}} / \mathrm{Pt}_{0.75 \mathrm{ML}} \mathrm{Cu}_{0.25 \mathrm{ML}} / \mathrm{Cu}(111)$. Blue: Pt; Brown: Cu; Red: O; White: $\mathrm{H}$.

Figure 8 Calculated segregation energy, $\Delta \mathrm{E}_{\mathrm{segr}}$, as a funcation of number of core $\mathrm{M}$ segregated to the surface, $\mathrm{Pt}_{(1-\mathrm{i}) \mathrm{ML}} \mathrm{M}_{\mathrm{iML}} / \mathrm{Pt}_{\mathrm{iML}} \mathrm{M}_{(1-\mathrm{i}) \mathrm{ML}} / \mathrm{M}$ (111) or (001), under the ORR condition: (a) *O; (b) *OOH.

Figure 9 The optimized structures of *OOH molecularly and dissociatively to $* \mathrm{O}$ and $* \mathrm{OH}$ on the core-shell alloy surfaces: (a) $\mathrm{Pt}_{1 \mathrm{ML}} / \mathrm{Cu}(111)$, $\mathrm{Pt}_{0.75 \mathrm{ML}} \mathrm{Cu}_{0.25 \mathrm{ML}} / \mathrm{Pt}_{0.25 \mathrm{ML}} \mathrm{Cu}_{0.75 \mathrm{ML}} / \mathrm{Cu}(111)$, (c) $\mathrm{Pt}_{0.5 \mathrm{ML}} \mathrm{Cu}_{0.5 \mathrm{ML}} / \mathrm{Pt}_{0.5 \mathrm{ML}} \mathrm{Cu}_{0.5 \mathrm{ML}} / \mathrm{Cu}(111)$, (d) $\mathrm{Pt}_{0.25 \mathrm{ML}} \mathrm{Cu}_{0.75 \mathrm{ML}} / \mathrm{Pt}_{0.75 \mathrm{ML}} \mathrm{Cu}_{0.25 \mathrm{ML}} / \mathrm{Cu}(111)$. Blue: Pt; Brown: $\mathrm{Cu}$; Red: O; White: $\mathrm{H}$. 